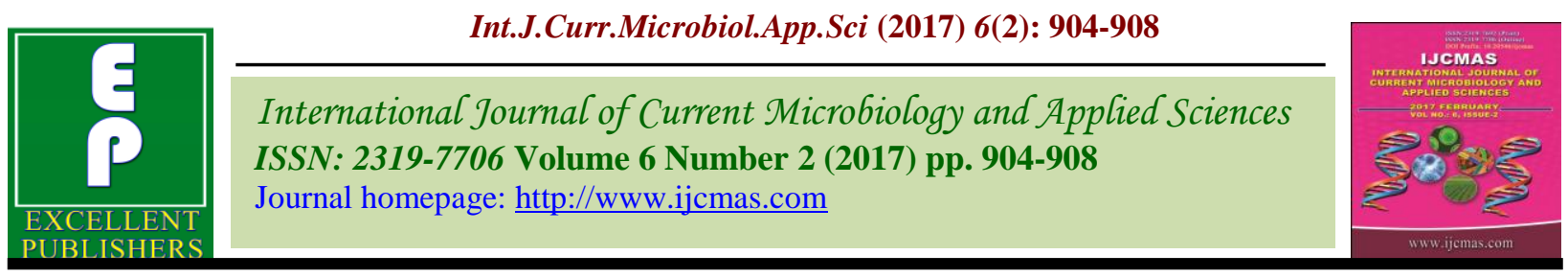

Original Research Article

http://dx.doi.org/10.20546/ijcmas.2017.602.101

\title{
Characterization of Irrigation Water and Extent of Sea Water Intrusion in Ground Water of Pondicherry Coastal Region, India
}

\author{
B. Guna ${ }^{1}$, C. Babou ${ }^{2}$ and G. Poyya Moli ${ }^{1}$ \\ ${ }^{1}$ School of Ecology and Environmental Sciences, Pondicherry University - 605 014, India \\ ${ }^{2}$ Presently working at Central Coffee Research Institute - 577 117, India \\ *Corresponding author
}

\section{A B S T R A C T}

\section{Keywords \\ Sea water intrusion, Ground waters, Quality indices.}

Article Info

Accepted:

20 January 2017

Available Online:

10 February 2017
An investigation was carried out in the Bahour commune of Pondicherry with a view to characterize the ground waters and characterization of irrigation water to develop management strategies to overcome the effect of poor quality water on soil and crop growth. Water samples were collected from 100 randomly selected wells during the summer seasons of 2010 - 13 and analyzed for their ionic composition. The results of the analysis of ground waters of Bahour region had shown that out of the 100 wells, the water samples from $98 \%$ of the well waters were dominated by sodium ion and the chloride to bicarbonate ratio indicated that 68 wells were found to be intruded with sea water. The classification of bore well waters based on EC and SAR had revealed that $64 \%$ under medium salinity medium sodicity. The electrical conductivity (EC) of the well waters ranged from 0.30 to $5.13 \mathrm{dS} \mathrm{m} \mathrm{m}^{-1}$ with a mean value of $1.48 \mathrm{dS} \mathrm{m}^{-1}$. The $\mathrm{pH}$ ranged from 7.04 to 8.87 . By considering the different classifications available under the various indices, it was concluded that the well waters of Bahour region was mostly saline with little sodicity hazard.

\section{Introduction}

Salinity and sodicity in soils and ground water have become major environmental issues due to the introduction of green revolution agriculture (GRA) in coastal areas (Vasanthakumar Reddy, 1999) and the dominance of GRA practices in coastal areas increased the ion concentration in soil and thus reducing yield both quantitatively and qualitatively and culminated in increased salinity of water and soil (Shannon, 1997). The existing salinity and sodicity problems will become worse due to rapidly growing human population in many countries and the increasing concerns over the limited water resources, which are forcing farmers to use poor quality water for irrigation (Zeng et al., 2002).

In Pondicherry region, the Bahour commune is considered to be the rice bowl of Pondicherry, wherein paddy is being cultivated continuously over centuries. The irrigation source in this commune is mainly through ground water, it is over exploited leading to sea water intrusion into the ground water (Vasanthakumar Reddy, 1999). The analysis of soil and water samples had indicated a very high concentration of 
sulphate ion in the ground water and as well as in the soil which had resulted in the reduction into hydrogen sulphide upon submergence. It was traced that the high concentration of sulphate in the soil was from the ground water which ultimately comes from the sea water.

With the above background, the present investigation was carried out to characterize the ground waters of Bahour region with the prime objective of identifying the extent of sea water intrusion into the ground waters and characterization of irrigation waters to suggest management practices to mitigate the ill effects of the poor quality water and soil on crop growth.

\section{Materials and Methods}

\section{Collection of irrigation water samples}

The water samples were collected in the 100 randomly selected wells (out of 1000 wells in study area) during summer seasons of 200713. The samples were collected in clean polythene bottles which were serially numbered. Before sampling, the motor was run for about 15 minutes, and the water was collected in the sample bottles after rinsing with the same bore well water. The sample bottles were tightly capped and brought to the laboratory for further analysis within three hours of sampling.

\section{Analysis of irrigation water}

The water samples were analysed for $\mathrm{pH}$, EC and for their ionic composition and various quality indices by employing standard methods (Table 1).

The sample bottles were tightly capped and brought to the laboratory for further analysis of cations and anions and quality parameters (pooled data) presented in tables 1 and 2.

\section{Results and Discussion}

\section{Characterization of irrigation water}

In the present study, well water samples (500 $\mathrm{ml}$ ) from 100 randomly selected tube wells in the Bahour commune were collected and analysed for the EC, $\mathrm{pH}$, cations (calcium, magnesium, sodium and potassium), anions (bicarbonate, carbonate, chloride and the sulphate) and various indices like RSC, RSBC, SAR, SSP and PS were derived to judge the classification of the irrigation waters / ground water and pooled data is presented in table 1 and 2.

It was also attempted to classify the water based on EC and SAR, according to USSL staff (1954), which further confirmed that 3 per cent of the well water samples were moderate saline, 80 per cent were medium saline, 16 per cent were high saline and 1 per cent were classified as very high saline. With regard to sodicity hazards, 11 per cent were classified as low sodic, 73 per cent as medium sodic, 15 per cent as high sodic and 1 per cent as very high sodic (Table 3 ).

\section{Extent of sea water intrusion in the ground waters}

Though these are various indices available to determine the sea water intrusion, the chloride to bicarbonate ratio was taken as an index in the present investigation due to the following reports of other workers. Krishna (1990) used the anion and cation sequence as an indication of sea water intrusion. It was reported that the sequence of $\mathrm{Ca}^{2+}>\mathrm{Mg}^{2+}>\mathrm{Na}^{2+}>\mathrm{K}^{+}$ indicates no sea water intrusion, $\mathrm{Na}^{2+}>\mathrm{Ca}^{2+}$ $>\mathrm{Mg}^{2+}>\mathrm{K}^{+}$indicates that the wells are in the process of sea water intrusion whereas, $\mathrm{Na}^{2+}$ $>\mathrm{Mg}^{2+}>\mathrm{Ca}^{2+}>\mathrm{K}^{+}$indicate that the wells are already intruded with sea water. Similarly, among the anions, the sequence of $\mathrm{HCO}_{3}{ }^{-}>$ $\mathrm{Cl}^{-}>\mathrm{SO}_{4}{ }^{2-}$ indicate no sea water intrusion, $\mathrm{Cl}$ 
- $>\mathrm{HCO}_{3}{ }^{-}>\mathrm{SO}_{4}{ }^{2-}$ indicate the process of sea water intrusion, $\mathrm{Cl}^{-}>\mathrm{SO}_{4}{ }^{2-}>\mathrm{HCO}_{3}{ }^{-}$indicate the completion of sea water intrusion. Similarly, the work of Baskar et al., (2003) had shown various ionic ratios like chloride to bicarbonate, chloride to sulphate, calcium to sodium, sodium to bicarbonate etc., wherein it was concluded that among all the ratios, the bicarbonate concentration is an important constituent to decide the sea water intrusion. Further work by Todd (1995) had indicated that the chloride to bicarbonate ratio is a better ratio to determine the sea water intrusion into the ground waters.

Accordingly, the results had suggested that out of 100 wells, 68 wells were found to be intruded with sea water (Table 1 and 2). Efforts were made in the present investigation to determine the causes for sea water intrusion, which indicates that neither the depth nor the distance from the sea determines the sea water intrusion. The soil of this study area has got river alluvium deposits up to $74 \mathrm{~m}$ in which zone the ground water was highly saline. Below this zone there is a layer of heavy clay between 74 to $89 \mathrm{~m}$ and 170 to $180 \mathrm{~m}$ leaving the zone of 89 to $179 \mathrm{~m}$ for sea water, from 180 to $210 \mathrm{~m}$, there are sandy deposits below which there are fresh waster aquifers. Similar results were reported by Baskar et al., (2003) and Babou et al., (2003).

As the ground water aquifers are already overexploited, farmers in this region target to exploit the fresh water below $210 \mathrm{~m}$ (>600 ft). However, when bore wells were dug and the perforated pipes were erected, the zone with high salt content ( 1 to $74 \mathrm{~m}$ ) and the sea water $(88$ to $170 \mathrm{~m})$ were not properly sealed leading to seeping in off the poor quality water and sea water into the fresh water, thereby causing salinization of the fresh water aquifers. This process occurs in most of the bore wells which were dug before 1980, during which time the technology was not available to seal the zones of contamination. However, the bore wells which were dug recently were properly sealed to prevent sea water seepage in to the fresh waters. In some cases, these wells also showed sea water intrusion which may be attributed to poor seepage or incorrect sealing of zones of contamination. This might be the possible reason for poor relationship between depth of the well and chloride to bicarbonate ratio.

Table.1 Results of analysis of cations and anions in the well waters of the Bahour

\begin{tabular}{|l|c|}
\hline $\begin{array}{c}\text { List of cations and anions } \\
\text { analysed in the water samples }\end{array}$ & Range (cmol L-1) \\
\hline Calcium $\left(\mathrm{Ca}^{2+}\right)$ & $0.40-8.60$ \\
\hline Magnesium $\left(\mathrm{Mg}^{2+}\right)$ & $0.00-19.00$ \\
\hline Sodium $\left(\mathrm{Na}^{+}\right)$ & $0.45-31.15$ \\
\hline Potassium $\left(\mathrm{K}^{+}\right)$ & $0.01-4.61$ \\
\hline Bicarbonate $\left(\mathrm{HCO}_{3}{ }^{-}\right)$ & $0.80-15.00$ \\
\hline Carbonate $\left(\mathrm{CO}_{3}{ }^{2-}\right)$ & $0.00-5.40$ \\
\hline Chloride $\left(\mathrm{Cl}^{-}\right)$ & $0.59-40.53$ \\
\hline Sulphate $\left(\mathrm{SO}_{4}{ }^{2-}\right)$ & $0.14-5.47$ \\
\hline
\end{tabular}


Table.2 Classification of well water based on quality indices in Bahour coastal region

\begin{tabular}{|c|c|c|c|c|}
\hline Properties / uints & $\begin{array}{c}\text { Methodology } \\
\text { used }\end{array}$ & Criteria & Description & $\begin{array}{l}\text { Wells in this } \\
\text { category }(\%)\end{array}$ \\
\hline $\mathrm{pH}$ & $\begin{array}{l}\text { USSL Staff } \\
\quad(1954)\end{array}$ & $\begin{array}{c}<6.00 \\
6.00-8.00 \\
>8.00\end{array}$ & $\begin{array}{l}\text { Acidic } \\
\text { Neutral } \\
\text { Alkaline }\end{array}$ & $\begin{array}{c}- \\
7 \\
93\end{array}$ \\
\hline $\mathrm{EC}\left(\mathrm{dSm}^{-1}\right)$ & $\begin{array}{l}\text { USSL Staff } \\
\text { (1954) }\end{array}$ & $\begin{array}{c}<0.25 \\
0.25-0.75 \\
0.75-2.25 \\
>2.25\end{array}$ & $\begin{array}{l}\text { Low } \\
\text { Medium } \\
\text { High } \\
\text { Very high }\end{array}$ & $\begin{array}{c}- \\
3 \\
79 \\
18\end{array}$ \\
\hline $\begin{array}{l}\text { Residual Sodium } \\
\text { Carbonate (RSC) } \\
\left(\mathrm{cmol} \mathrm{L}^{-1}\right)\end{array}$ & Eaton (1950) & $\begin{array}{c}<1.25 \\
1.25-2.50 \\
>2.50\end{array}$ & $\begin{array}{l}\text { Good } \\
\text { Fair } \\
\text { Unsuitable }\end{array}$ & $\begin{array}{l}43 \\
26 \\
31\end{array}$ \\
\hline $\begin{array}{l}\text { Sodium Adsorption } \\
\text { Ratio (SAR) }\end{array}$ & $\begin{array}{l}\text { USSL Staff } \\
\text { (1954) }\end{array}$ & $\begin{array}{c}<10 \\
10-18 \\
18-26 \\
>26\end{array}$ & $\begin{array}{l}\text { Low } \\
\text { Medium } \\
\text { High } \\
\text { Very high }\end{array}$ & $\begin{array}{c}69 \\
30 \\
1 \\
-\end{array}$ \\
\hline $\begin{array}{l}\text { Soluble Sodium } \\
\text { Percentage (SSP) } \\
(\%)\end{array}$ & $\begin{array}{l}\text { USSL Staff } \\
\text { (1954) }\end{array}$ & $\begin{array}{l}<60 \\
>60\end{array}$ & $\begin{array}{l}\text { Suitable } \\
\text { Unsuitable }\end{array}$ & $\begin{array}{l}14 \\
86\end{array}$ \\
\hline $\begin{array}{l}\text { Potential Salinity } \\
(\mathrm{PS})\left(\mathrm{cmol} \mathrm{L}^{-1}\right)\end{array}$ & Doneen (1963) & $\begin{array}{c}3-7 \\
8-15 \\
16-20\end{array}$ & $\begin{array}{l}\text { Safe with low } \\
\text { permeability } \\
\text { Safe with medium } \\
\text { permeability } \\
\text { Safe with good } \\
\text { permeability }\end{array}$ & $\begin{array}{l}77 \\
21 \\
2\end{array}$ \\
\hline $\begin{array}{l}\text { Ratio of } \mathrm{Cl}^{-} \text {to } \\
\mathrm{HCO}_{3}^{-}\end{array}$ & Todd (1995) & $\begin{array}{l}<1 \\
>1 \\
\end{array}$ & $\begin{array}{l}\text { No intrusion } \\
\text { Intrusion }\end{array}$ & $\begin{array}{l}32 \\
68 \\
\end{array}$ \\
\hline $\begin{array}{l}\text { residual sodium } \\
\text { bicarbonate } \\
(\mathrm{RSBC})\left(\mathrm{cmol} \mathrm{L}^{-1}\right)\end{array}$ & Gupta (1984) & $\begin{array}{c}<5 \\
5-10 \\
>10\end{array}$ & $\begin{array}{l}\text { Safe } \\
\text { Marginal } \\
\text { Unsatisfactory }\end{array}$ & $\begin{array}{l}81 \\
19 \\
-\end{array}$ \\
\hline
\end{tabular}

Table.3 Classification of irrigation water based on EC and SAR in Bahour coastal region

\begin{tabular}{|c|l|l|c|}
\hline Sl. No & \multicolumn{1}{|c|}{ Classification } & Wells in this category (\%) \\
\hline 1 & $\mathrm{C}_{2} \mathrm{~S}_{1}$ & Moderate salinity low sodicity & 3 \\
\hline 2 & $\mathrm{C}_{3} \mathrm{~S}_{1}$ & Medium salinity low sodicity & 8 \\
\hline 3 & $\mathrm{C}_{3} \mathrm{~S}_{2}$ & Medium salinity medium sodicity & 64 \\
\hline 4 & $\mathrm{C}_{3} \mathrm{~S}_{3}$ & Medium salinity high sodicity & 9 \\
\hline 5 & $\mathrm{C}_{4} \mathrm{~S}_{2}$ & High salinity medium sodicity & 6 \\
\hline 6 & $\mathrm{C}_{4} \mathrm{~S}_{3}$ & High salinity high sodicity & 1 \\
\hline 7 & $\mathrm{C}_{4} \mathrm{~S}_{4}$ & High salinity very high sodicity & 1 \\
\hline 8 & $\mathrm{C}_{5} \mathrm{~S}_{3}$ & Very high salinity high sodicity & \\
\hline
\end{tabular}

From the foregoing discussion, it can be concluded that the well water samples of the study area are mostly saline with medium sodicity hazards in some of the wells. Though it was concluded that 98 per cent of the well waters were dominated by sodium ion, which 
was related to the sea water intrusion, the various quality indices had indicated that the waters were only having limited hazards with respect to sodicity. This may be attributed to higher proportion of the divalent cations viz., calcium and magnesium that might have compensated the excess quantities of sodium in the ground waters. Similar results were reported by Somani (1998) and Baskar et al., (2003).

The soils of Bahour region were being continuously irrigated with such poor quality water (water containing certain ions in dominant proportions like sodium, chloride, boron) over years, resulting in the significant rise in the salinity of the soil. Besides, irrigating the soil with poor quality may cause nutrient imbalances, thereby affecting the ultimate soil biota. The soils of the study area belong to Bahour soil series. The EC of the soil was ranges from $1.86-4.56 \mathrm{dSm}^{-1}$ and the $\mathrm{pH}$ was ranges from $8.22-9.0$. This result is similar with Baskar et al., (2003) and Vasanthakumar Reddy (1999). From this investigation it is concluded that the well waters of Bahour region was mostly saline with little sodicity hazard and the study area was affected by continues use of poor quality water.

\section{References}

Babou, C., Poyyamoli, G., and B. Guna. 2009. Impact of LEISA based system of rice intensification (SRI) practices on rice grain yield and soil properties in ricerice-rice cropping system in Pondicherry region. Int. J. Agri. Sci., 5(1): $43-45$

Baskar, A., Sankaran, R., and P. Selvaraj. 2003.
Influence of sea water intrusion on soil chemical properties. Paper presented in the National seminar on advances in agricultural resource management held at $\mathrm{AC}$ and RI, Killikulam on 22 September, 2003.

Doneen, L.D. 1963. Water quality for agriculture department of irrigation, University of California, Davis. 48

Eaton, F.M. 1950. Significance of Carbonate in irrigation water. Soil Sci., 69: 123-133.

FAO. 2005. Report of the regional workshop on salt-affected soils from sea water intrusion: strategies for rehabilitation and management 31 March 2005, Thailand.

Gupta, I.C. 1984. Reassessment of irrigation water quality - criteria and standards. Curr. Agric., 8(3\&4): 109-121.

Krishna, G. 1990. Chemical parameters rations for identifying the sea water encroachment in coastal aquifers of an alluvium formation. J. Appl. Hydrol., 1: 37.

Shannon, M.C. 1997. Adaptation of plants to salinity. Adv. in Agron., 60: 75-120.

Somani, L.L. 1998. Crop production with saline water. Agro Botanica, New Delhi. 1-308.

Todd, D.K. 1995. Ground water hydrology. John Willey and sons. p: 516.

USSL Staff. 1954. Diagnosis and improvement of Saline and Alkaline soils. USDA Hand book, 60. 147.

Vasanthakumar Reddy. 1999. Perspectives plan of water resources in Pondicherry. Public Works Department, Government of Pondicherry. 1- 8.

Zeng, L., Shannon, and Grieve, C.M. 2002. Evaluation of salt tolerance in rice 32 genotypes by multiple agronomic parameters. Euphytica, 127: 235-245.

\section{How to cite this article:}

Guna, B., C. Babou and Poyya Moli, G. 2017. Characterization of Irrigation Water and Extent of Sea Water Intrusion in Ground Water of Pondicherry Coastal Region, India. Int.J.Curr.Microbiol.App.Sci. 6(2): 904-908. doi: http://dx.doi.org/10.20546/ijcmas.2017.602.101 